\title{
One Size Fits All? Decentralization, Corruption, and the Monitoring of Bureaucrats
}

\author{
CHRISTIAN LESSMANN \\ GUNTHER MARKWARDT
}

CESIFO WORKING PAPER No. 2662

Category 2: Public Choice

MAY 2009
An electronic version of the paper may be downloaded
- from the SSRN website:
- from the RePEc website:
- from the CESifo website:
www.SSRN.com
www.RePEc.org
www.CESifo-group.org/wp




\title{
One Size Fits All? Decentralization, Corruption, and the Monitoring of Bureaucrats
}

\begin{abstract}
The majority of theoretical and empirical studies on the relationship between decentralization and corruption argues that the devolution of power might be a feasible instrument to keep corruption at bay. We argue that this result crucially depends on the effectiveness of monitoring bureaucrat's behavior. The benefits of interjurisdictional competition only occur if there is a supervisory body such as a free press, which is often lacking in less-developed countries. Using cross-country data, we analyze the relationship between decentralization and corruption taking different degrees of the freedom of the press into account. Our main finding is that decentralization counteracts corruption in countries with high degrees of press freedom, whereas countries without effective monitoring suffer from decentralization. Our policy implication is that a free press is a necessary pre-condition for successful decentralization programs.
\end{abstract}

JEL Code: D73, H77, O23.

Keywords: decentralization, corruption, freedom of press.

\author{
Christian Lessmann \\ Dresden University of Technology \\ Faculty of Business and Economics \\ Chair of Public Economics \\ 01062 Dresden \\ Germany \\ christian.lessmann@tu-dresden.de
}

\author{
Gunther Markwardt \\ Dresden University of Technology \\ Faculty of Business and Economics \\ Chair of Public Economics \\ 01062 Dresden \\ Germany \\ gunther.markwardt@tu-dresden.de
}

20 May 2009

We would like to thank Marcel Thum, the brown bag seminar participants at the Dresden University of Technology and at the Simon Fraser University Vancouver and the seminar participants of the annual meeting of the Public Choice Society in Las Vegas (2009). The usual disclaimer applies. 


\section{Introduction}

It is a consensus that corruption is one of the most serious problems in developing countries, in the scientific as well as in the public discussion. The question of how to tackle corruption in developing countries is not yet answered convincingly. One repeatedly proposed solution is to implement bureaucratic or inter-regional competition through fiscal decentralization [see, e.g., Fisman and Gatti (2002a) or Arikan (2004)]. Competition might strengthen the accountability of bureaucrats and, thus, reduce the ability of public officials to extract rents. Referring to these arguments, the poverty reduction programs of international institutions contain decentralization as a substantive instrument. For example, 12 percent of World Bank projects completed between 1993 and 1997 involved decentralizing responsibilities to lower levels of government [Litvack et al. (1998)]. More recently, in 2006 more than 19 percent, or 4.5 billion dollars, of the World Bank budget was spent on decentralization projects [Development Committee (2006)]. Nevertheless, there is some doubt concerning the effectiveness of this development strategy.

To assess whether or not decentralization is recommendable for a certain policy purpose, it is necessary to analyze the effects of decentralization considering the whole country-specific institutional framework. Although most empirical studies found lower corruption in decentralized countries, we argue that the positive effects of decentralization do not prevail if comprehensive public monitoring does not exist. The main questions of our paper are the following: Can we identify a complementary relationship between decentralization and the effectiveness of monitoring of bureaucrats and its influence on corruption? Is decentralization in either case the right medicine against the corruption disease? Or in short, does one size fits all?

For this purpose we estimate a cross-section of 64 countries using alternative decentralization and corruption measures. We show that the established positive effect of decentralization disappears for most specifications in our broader data set. We thereafter estimate a structural break model, controlling for a complementary relationship between decentralization and the effectiveness of public monitoring of bureaucrats measured by the index of freedom of the press. Our main finding is that decentralization counteracts corruption in countries with a high degree of freedom of the press, while countries with a low degree of freedom of the press suffer from decentralization. Our results imply that decentralization projects in developing countries should be accompanied by other institutions acting as supervisory body that strengths accountability of bureaucrats, such as a free press.

The paper is organized as follows. Section 2 briefly reviews the related theoretical and empirical literature and discusses the extent to which the results are applicable for developing countries. Section 3 describes our data and empirical methodology. Section 4 presents the estimation results and robustness checks. Section 5 concludes. 


\section{Related literature}

\subsection{Some theoretical considerations}

The predictions of theoretical models concerning the impact of decentralization on corruption are ambiguous. Models favoring decentralization are based on the implicit assumption that a working information infrastructure exists within a country. For example, yardstick competition models assume that people could compare policy outcomes in their home jurisdiction with neighboring regions, requiring free information flows. Similarly, models based on a tax-competition framework need free information flows as well as mobile capital and/or labor. The mechanism driving corruption down in such models is (political) competition. Shleifer and Vishny (1993) argue that "Countries with more political competition have stronger public pressure against corruption through laws, democratic elections, and even the independent press - and so are more likely to use government organizations that contain rather than maximize corruption proceeds."[Shleifer and Vishny (1993), p. 610]. There are also models implying a negative impact of decentralization on corruption. These models emphasize the danger of close connections between local interest groups and local decision makers.

In their seminal paper, Shleifer and Vishny (1993) discuss corruption in a double marginalization framework. They argue that different monopolistic bureaucrats set their bribery demands independently in order to maximize their own benefit without taking the negative externalities on other bureaucrats into account. In this case, vertical decentralization leads to greater dispersion of government decision-making powers, and the lack of coordination among bureaucrats results in excessive rent extraction. ${ }^{2}$ However, Shleifer and Vishny (1993) also emphasize that horizontal decentralization leads to decreasing corruption through strengthening the competition between bureaucrats.

Prud'homme (1995) provides an argument against decentralization. He argues that there are more opportunities for corruption at the local level because local politicians and bureaucrats are likely to be more subject to the pressing demands of local interest groups. Moreover, local decision makers have usually more discretionary powers than national officials, increasing the negative effect of decentralization. He also discusses the role of an independent press in the context of decentralization and corruption, arguing that "In some countries, at least, national bureaucracies have a tradition of honesty that is often absent at the local level. The pressure of media, inasmuch as it exists, would also be a greater disincentive at the national than at the local level" [Prud'homme (1995), p. 211]. In the same vein, Tanzi (1995) argues on the basis of

2 A timely application of the Shleifer and Vishny (1993) model is provided by Bennett and Estrin (2006). The authors analyze the relationship between centralized or decentralized infrastructure provision and corruption in developing economies. The impact of decentralization on corruption was ambiguous depending on the efficiency of the tax system, the venality of bureaucrats, and other issues. 
local interest groups. He states that corruption may be more common at the local level compared to the national level, in particular in developing countries. Local officials live closer to the citizens and this contiguity leads to a higher impact of local interest groups and a higher level of corruption in decentralized countries.

An ambiguous effect of decentralization on corruption appears if the quality of bureaucrats is considered. Persson and Tabellini (2000a) assume that working in a central government provides more prestige and power to the agents in contrast to a local government. Thus, monitoring may be more intense on the central level, and efforts by centralized bureaucrats may be greater, reducing corruption.

However, Persson and Tabellini (2000a) discuss that this effect is mitigated by differences in central and local bureaucrats' responsibilities. Central bureaucrats are responsible for various tasks and localities simultaneously, whereas under decentralization, agents are often responsible for a single task in a single jurisdiction. In the first case, only the aggregate performance of politicians matters for reappointment. The indirect accountability weakens the incentives to perform well, since there is a smaller link between effort and rewards. In contrast, in a decentralized government, decision makers are held accountable for all of their actions. Therefore, decentralization may increase fiscal performance and decrease corruption. The equilibrium impact of decentralization on corruption remains unclear.

More recent studies rely on competition between jurisdictions. Applying a tax-competition framework, Arikan (2004) shows that an increasing degree of competition for mobile capital between jurisdictions leads to less corrupt bureaucrats. In the yardstick competition model by Dincer et al. (2006) voters compare the policy outcomes in their home jurisdiction with their neighbor regions and thus implement interregional competition. Under certain circumstances, this yardstick competition may lead to lower levels of corruption. ${ }^{3}$ As mentioned at the beginning of this section, it is noteworthy to examine the application of these theoretical models to developing countries.

Studies on decentralization and corruption considering the specific institutional problems of developing countries are rare. A criticism of the applicability of the classical Tiebout (1956) approach to developing countries brings up Bardhan (2002), arguing: "(...) the information and accounting systems and mechanisms of monitoring of public bureaucrats are much weaker in low-income countries. (...) Thus, the differential efficacy of such mechanisms under centralization and decentralization becomes important" [Bardhan (2002), p. 188]. Moreover, he argues that mechanisms of political account-

3 Careaga and Weingast (2000) and Rodden (2000) contribute to the literature on decentralization and corruption by distinguishing between different kinds of decentralization. It turns out to be important whether the expenditures of sub-national governments are financed by own revenue sources or not, because central government transfers give local decision makers the incentive to ignore the budgetary consequences of their mismanagement. 
ability are especially weak in developing countries, and "(..) any discussion of delivery of public services has to grapple with issues of capture of governments at different tiers by elite groups more seriously than is the custom in the traditional decentralization literature." 4 With capture of local governments, in the sense of elites receiving a larger weight in the local government's welfare function, there is a tendency for the local government to provide a service to local elites excessively at the expense of the nonelite [Bardhan and Mookherjee (2006a)]. Therefore, in developing countries, there is no a priori verdict in favor of decentralization. The existence of appropriate monitoring abilities might influence the impact of decentralization on corruption.

All in all, an important issue is that in almost all theoretical model which favor decentralization, the free flow of information plays an important role. If the monitoring of bureaucrats works, decentralization might indeed decrease corruption through political competition. A free and independent press is able to reveal and report misuses of public office for private gain. It complements the competition and accountability effects of decentralization. Persons concerned with corruption can reveal the bureaucrat's behavior to a journalist and the media reports will raise the costs for the bureaucrat as the probability of being detected and punished is increased. Conversely, if the press is under the control of an autocratic administration, the abuse of authority is virtually less risky for bureaucrats. In this case, decentralization does not work. However, in most developing countries the existing information infrastructure is controlled by corrupt or autocratic officials. Assumptions of models favoring centralization seem to be more appropriate for developing countries. Our hypothesis is that decentralization is a suitable instrument for controlling corruption in countries with an appropriate information infrastructure, while countries without these necessary information flows may suffer from decentralization.

\subsection{Previous empirical studies on corruption and decentralization}

The majority of empirical studies have found corruption to be lower in decentralized countries. These studies, however, do not consider the weak institutional structure of developing countries, such as the low degree of press freedom, which hampers the public monitoring of bureaucrats. In the following, we survey the most important empirical studies and discuss possible extensions in respect to our main research question.

An initial empirical investigation is provided by Huther and Shah (1998), who found a negative correlation between the degree of expenditure decentralization and the level of corruption. Corruption is measured by a governance index for 80 developed and developing countries. They report a significant Pearson correlation coefficient, but due to the fact that no control variables are considered, omitted variables might bias the

$\overline{4}$ See Bardhan and Mookherjee (2006b) and Bardhan and Mookherjee (2006a) for details. 
results. Furthermore, from correlation it is not necessarily possible to draw conclusions about the causal relationship.

Treisman (2000) analyzes the causes of corruption and takes the federal structure into account. He finds a negative relationship between a dummy variable reflecting whether a country has a federal or unitary constitution and the absence of corruption. ${ }^{5}$ In contrast to the aim of our paper such a federal dummy does not necessarily reflect 'de facto' decentralization. The existence of a federal constitution itself does not necessarily reflect that sub-national governments have appreciable authority or autonomy in decision making. The study of Treisman (2000) is, thus, not comparable to the results of other papers measuring decentralization through financial accounts or the like. ${ }^{6}$

A positive impact of fiscal decentralization on the absence of corruption is found by Fisman and Gatti (2002a). However, with regard to our theoretical discussion in section 2.1 the results of this study remain inconclusive concerning to the effects of decentralization in less developed countries. The authors do not consider subsamples for less developed countries, taking into account that the influence of decentralization on corruption may be reversed in different institutional frameworks as suggested by Prud'homme (1995), Litvack et al. (1998), Bardhan (2002), and others. Nevertheless, we use this influential study as benchmark for ours.

Fisman and Gatti (2002b) study the relationship between corruption in U.S. states and dependency on central government transfers. They found corruption is positively associated with larger federal transfers. Moreover, their results imply that different types of decentralization do not always have the same impact on corruption, supporting theoretical predictions of Careaga and Weingast (2000) and Rodden (2000).

A comparable study to Fisman and Gatti (2002a) is Arikan (2004), who analyzes the impact of several decentralization measures on Transparency International's Corruption Perceptions Index in a cross-country data set. She also found corruption to be lower in decentralized countries. However, considering endogeneity, the weak significant relationship turned to insignificance in almost all estimation specifications. Lederman et al. (2005) analyze the impact of different political institutions including decentralization on corruption based on a panel data set of several developed and developing countries. Using the International Country Risk Guide's (ICRG) corruption index, they find that central government transfers to other levels of national government decreases corruption.

Dincer et al. (2006) analyze U.S. state level corruption and dependency on the degree of expenditure decentralization in a panel data set. They find some evidence for corruption

$\overline{5}$ Note that almost all studies, like ours, use corruption measures which have high values for a low level of corruption, thereby measuring the 'absence of corruption'. See section 3.2 for details.

6 See section 3.1 for details on the measurement of decentralization. 
being smaller in more decentralized states as well as strong evidence for the effects of yardstick competition. However, the results do not remain significant when trying to handle the problems arising from endogeneity.

Freille, Haque and Kneller (2007a) analyzes the impact of different fiscal and constitutional decentralization measures on corruption within a cross section data set of 177 countries. Their results suggest that both fiscal decentralization and constitutional centralization are simultaneously associated with lower corruption. In contrast to the most other studies they make use of a wide range of different decentralization indicators e.g. fiscal, constitutional, political and structural decentralization measures. However, similar to the other studies discussed in our literature survey, they do not consider possible complementary effects of decentralization and the effectiveness of monitoring of bureaucrats. All studies discussed are summarized in Table 1.

Table 1

Previous empirical studies

\begin{tabular}{|c|c|c|c|}
\hline Author(s) & $\operatorname{Data}^{a), b), c)}$ & Methodology & Results $^{d)}$ \\
\hline \multirow{2}{*}{$\begin{array}{l}\text { Huther Shah } \\
\text { (1998) }\end{array}$} & a) 80 countries & \multirow[t]{2}{*}{ Pearson correlation } & \multirow[t]{2}{*}{ positive } \\
\hline & $\begin{array}{l}\text { b) 'good governance' measure } \\
\text { c) expenditure decentralization }\end{array}$ & & \\
\hline \multirow{2}{*}{$\begin{array}{l}\text { Treisman } \\
(2000)\end{array}$} & a) up to 64 countries & cross country & \multirow[t]{2}{*}{ negative } \\
\hline & $\begin{array}{l}\text { b) CPI index, Business international, } \\
\text { and Global competitiveness survey } \\
\text { c) federal dummy }\end{array}$ & WLS and OLS & \\
\hline \multirow{2}{*}{$\begin{array}{l}\text { Fisman Gatti } \\
(2002 a)\end{array}$} & a) up to 55 countries & cross country & \multirow[t]{2}{*}{ positive } \\
\hline & $\begin{array}{l}\text { b) CPI index, ICRG index, World } \\
\text { competitiveness report, German ex- } \\
\text { porter index, Business international, } \\
\text { and Global competitiveness survey } \\
\text { c) expenditure decentralization }\end{array}$ & OLS and TSLS & \\
\hline \multirow{2}{*}{$\begin{array}{l}\text { Fisman Gatti } \\
(2002 b)\end{array}$} & a) 50 U.S. states & cross country & \multirow[t]{2}{*}{ positive } \\
\hline & $\begin{array}{l}\text { b) convictions for abuse of public office } \\
\text { c) share of federal transfers }\end{array}$ & OLS & \\
\hline \multirow{3}{*}{$\begin{array}{l}\text { Arikan } \\
(2004)\end{array}$} & a) 40 countries & cross country & \multirow[t]{3}{*}{ positive } \\
\hline & b) CPI index & OLS and TSLS & \\
\hline & $\begin{array}{l}\text { c) number of local jurisdictions, share } \\
\text { of non-government employment, ex- } \\
\text { penditure decentralization }\end{array}$ & & \\
\hline \multirow{3}{*}{$\begin{array}{l}\text { Lederman et al. } \\
(2005)\end{array}$} & a) 102 countries & panel & \multirow[t]{3}{*}{ positive } \\
\hline & b) ICRG index & $\begin{array}{l}\text { pooled OLS, ordered pro- } \\
\text { bit }\end{array}$ & \\
\hline & c) central transfers & & \\
\hline \multirow{2}{*}{$\begin{array}{l}\text { Dincer et al. } \\
(2006)\end{array}$} & a) 48 U.S. states & panel & \multirow[t]{2}{*}{ positive } \\
\hline & $\begin{array}{l}\text { b) convictions for abuse of public office } \\
\text { c) expenditure decentralization }\end{array}$ & pooled OLS, RE and TSLS & \\
\hline \multirow{3}{*}{$\begin{array}{l}\text { Freille et al. } \\
(2007 \mathrm{a})\end{array}$} & a) up to 177 countries & cross section & \multirow[t]{3}{*}{ positive } \\
\hline & $\begin{array}{l}\text { b) CPI index, ICRG index, World com- } \\
\text { petitiveness report }\end{array}$ & OLS and rolling regression & \\
\hline & c) different decentralization measures & & \\
\hline
\end{tabular}




\subsection{Previous empirical studies on corruption and freedom of press}

The decision to participate in corrupt practices (like any other crime) mainly depends on three factors. The benefit factor is the size of payoffs that can be received by corruption. The costs of corruption depends the threatened amount of punishment when being caught. The third combining factor is the probability of detection (see Becker (1968)). A free and independent press is an important part of the detection process and therefore lowers the expected utility of corruption. The majority of empirical studies found that a free press is associated with lower corruption. In the following, we survey the most important studies.

An initial empirical investigation is provided by Stapenhurst (2000), who find a negative correlation between the freedom press and the level of corruption. He reports a significant Pearson correlation coefficient, but due to the fact that no control variables are considered, omitted variables might bias the results. Furthermore, from correlation it is not necessarily possible to draw conclusions about the causal relationship.

Arend (2002) analyzes the relationship between corruption, press freedom and human capital in a panel data set. He finds evidence for corruption being smaller in countries with a higher degree of freedom of the press. Ahrend emphasizes that a high degree of press freedom acts as a channel through which education decreases corruption.

Brunetti and Weder (2003) test for a large number of countries the hypothesis that a free press is associated with lower levels of corruption. Brunetti and Weder use the ICRG index and the press freedom measure provided by Freedom House. They find strong empirical evidence for a negative relation between the freedom of press and corruption.

In contrast to other previous studies, Chowdhury (2004) analyzes the impact of the freedom of press jointly with the level of democracy on corruption. Following Persson and Tabellini (2000b) he proposes the following theoretical channel between the three variables: First, the ability to monitor bureaucrats by a free press brings corruption cases to the voters, and second, the voters in a democracy punish corrupt politicians by ousting them from public offices (see Chowdhury (2004), p. 93). He concludes that both freedom of press and democracy are significant controls on corruption.

Lederman et al. (2005) analyze the relationship between several political institutions and corruption. They only find weak evidence of an impact freedom of the press on the level of corruption. The coefficient on press freedom becomes insignificant when they include a control variable of economic development in the regression.

The most resent study is by Freille, Haque and Kneller (2007b). The authors test the relationship between press freedom and corruption performing a extrem bound analysis. They find evidence that both political and economic influences on the media are strongly and robustly related to corruption, while detrimental laws and regulations 
influencing the media are not. However, none of the surveyed studies examines the possible complementary influence of decentralization and freedom of press on corruption. The discussed studies are summarized in Table 2.

Table 2

Previous empirical studies II

\begin{tabular}{|c|c|c|c|}
\hline Author(s) & $\operatorname{Data}^{a), b), c)}$ & Methodology & Results $^{d)}$ \\
\hline Stapenhurst & a) 51 counties & Pearson correlation & positive \\
\hline \multirow[t]{2}{*}{$(2000)$} & b) CPI index & & \\
\hline & c) Freedom House Index & & \\
\hline \multirow{3}{*}{$\begin{array}{l}\text { Ahrend } \\
(2002)\end{array}$} & a) 109 countries & panel & positive \\
\hline & b) ICRG index & OLS & \\
\hline & c) Freedom House index & & \\
\hline \multirow{3}{*}{$\begin{array}{l}\text { Brunetti and Weder } \\
(2003)\end{array}$} & a) 125 countries & cross section, panel & positive \\
\hline & b) ICRG index & OLS, TSLS, PROBIT & \\
\hline & c) Freedom House index & & \\
\hline \multirow{3}{*}{$\begin{array}{l}\text { Chowdhury } \\
\text { (2004) }\end{array}$} & a) 97 countries & cross section, panel & positive \\
\hline & b) CPI index & OLS, TSLS, GMM & \\
\hline & c) Freedom House index & & \\
\hline \multirow{3}{*}{$\begin{array}{l}\text { Lederman et al. } \\
(2005)\end{array}$} & a) 145 countries & panel & insignificant \\
\hline & b) GCS, ICRG, WDR & OLS, PROBIT & \\
\hline & c) Freedom House index & & \\
\hline \multirow{3}{*}{$\begin{array}{l}\text { Freille et al. } \\
(2007 b)\end{array}$} & a) 51 countries & panel & positive \\
\hline & b) CPI index, ICRG index & OLS, EBA, GMM & \\
\hline & c) Freedom House index (disaggreg.) & & \\
\hline
\end{tabular}

While the relationship between decentralization and corruption is ambiguous in the theoretical literature, the majority of empirical studies found corruption to be lower in decentralized countries. Although parts of the theoretical literature emphasize that the impact of decentralization on corruption depends on the effectiveness of monitoring of bureaucrats, none of these studies has considered this issue explicitly. The aim of our paper is to investigate whether the public monitoring - reflected by freedom of the press - has an impact on the influence of decentralization on corruption as discussed by Shleifer and Vishny (1993), Prud'homme (1995), Bardhan (2002) among others. For this purpose we estimate a structural break model considering complementary effects of decentralization and freedom of the press.

\section{The data}

\subsection{Decentralization measures}

The proper definition of applicable decentralization measures is a challenging task. Several measurement concepts have been elaborated in the literature. ${ }^{7}$ One possibility for the measurement of decentralization is to design indicators for the organization of

$\overline{7}$ Excellent overviews of the problems of measuring fiscal decentralization are provided by Treisman (2002), Rodden (2004) and Stegarescu (2005). 
governments with respect to laws and institutions from a political economy perspective. In particular, the indices of Treisman (2002) have often been used in the recent literature, and thus, we adopt them for our analysis. Among others, Treisman has created two decentralization measures: a federal dummy (FEDERAL) capturing whether a federal constitution exists (1) or not (0) and a measure for the number of vertical government tiers $(T I E R S)$. As these measures are constructed from formal national law, we classify them as 'de jure' decentralization measures. Thus, these measures do not necessarily reflect sub-national government authority or autonomous power in decision making. For this purpose we use 'de facto' decentralization measures, factoring in the financial resources of sub-national governments as compared to the central government. To measure 'de facto' decentralization, we construct measures using the IMF's Government Finance Statistics (GFS), which provides data on central, state, and local government revenues and expenditures for several developed and developing countries since the early 1970s. Decentralization indices are calculated by relating the sum of state and local expenditures (revenues) to the consolidated total government expenditures (revenues). We use EXPDEC as an abbreviation for the degree of expenditure decentralization and $R E V D E C$ for the degree of revenue decentralization.

Oates (1972) discusses the general limitations of such 'classical' decentralization measures. He basically argues that these measures do not always represent the actual degree of decentralization because it is also important to consider the autonomy of sub-national governments in expenditure or revenue decisions. Otherwise, if sub-national autonomy is not taken into account, the 'classical' decentralization measures would indicate a high level of decentralization, although a wide range of sub-national expenditure and revenue decisions is determined by the federal government. For this reason, the OECD has developed an internationally comparable framework to assess the degree of control sub-central governments have over their revenues [see OECD (1999)]. Several authors, e.g. Rodden (2004) and Stegarescu (2005), have applied this framework to create new decentralization measures reflecting autonomy of sub-national jurisdictions. However, as the data source suggests, these decentralization measures are available only for OECD countries and therefore not applicable for a wide range of countries.

Following Arikan (2004), we consider a fifth alternative decentralization measure, which can be derived from the employment statistics compiled by the International Labor Organization (ILO). These statistics contain data on public (and private) employment, distinguishing between the national and sub-national government levels for numerous countries. In the same manner as we proceeded with the other 'de facto' decentralization measures, we can calculate the share of sub-national government employment $(E M P L D E C)$, which is the ratio of sub-national government employment to total government employment. Table A1 in the appendix reports the correlations for all decentralization measures. Except for TIERS, all measures are positively correlated. 


\subsection{Corruption measures}

Besides measures of decentralization, we also need adequate measures of corruption. We make use of three different commonly applied measures of corruption. The first measure is the corruption index provided by the PRS Group in the International Country Risk Guide (ICRG). This measure reflects the likelihood that government officials will demand special payments and the extent to which illegal payments are expected throughout lower levels of government. The ICRG index is based on a survey of international experts and has been available since the early 1980s [see Knack and Keefer (1995)]. A second corruption index is provided by the World Bank and is commonly known as the Kaufman index $(W B C)$. This indicator is available beginning in 1996 . The third corruption measure, the corruption perception index $(C P I)$, is provided by Transparency International. The index is available beginning in 1980, but due to the composition of the index, not comparable between years. ${ }^{8}$

All of these measures reflect the absence of corruption: This means that a high value indicates low corruption. The $I C R G$ index is defined between 0 and 6 , the $W B C$ index between -2.5 and +2.5 , and the $C P I$ index between 0 and 10 . For reasons of better comparability of our different estimation results, we have rescaled all three measures so that they have values between zero (most corrupt) and one (least corrupt).

\subsection{Monitoring of Bureaucrats - Freedom of the press measure}

The aim of our study is to investigate whether the effectiveness of monitoring of bureaucrats determines the impact of decentralization on corruption. A commonly used proxy for the observability of bureaucratic behavior is the index for freedom of the press (e.g. Brunetti and Weder (2003)). We follow this approach and revert to the index for freedom of the press provided by Freedom House. The data is available from 1980 to the present and currently covers 194 countries. Country narratives examine the legal environment for the media, political pressures that influence reporting, economic factors that affect access to information, and repressive actions against journalists. These four categories are rated for the print media as well as the broadcast media. The overall index ranges from 0 (total freedom of the press) to 100 (highest violation of press freedom). Note that we have rescaled the index in such a way that high values indicate a high degree of freedom of the press and low values the opposite.

\subsection{Other explanatory variables}

As the level of corruption in a country is not solely determined by decentralization and freedom of press, our estimations include several control variables following previous

8 A discussion of time-series properties of the index is provided by Lambsdorff (2005). Panel data analysis is possible with a special data set starting in 1995. 
cross-country studies, e.g., the studies by Fisman and Gatti (2002a) and Arikan (2004).

Our baseline regression includes as control variables: the log of population size (POP), the log of gross domestic product per capita in dollars at constant prices of the year $2000(G D P P C)$, the sum of exports and imports as a share of GDP as a measure for the degree of openness $(G L O B A L)$, the diversity index of ethnic fractionalization (ETHNO), and the share of government expenditures in GDP as a measure for government size (GOVSIZE). Most of the data is provided by the World Bank in the World Development Indicators 2006 (WDI). One exception is ethnic fractionalization, which is provided by www.ethnologue.com. ${ }^{9}$ Table 3 provides summary statistics of the variables.

Table 3

Summary statistics, cross country data

\begin{tabular}{lcrrrr}
\hline Variable & Obs. & Mean & Std. Dev. & Min & \multicolumn{1}{c}{ Max } \\
\hline ICRG $(0 \ldots 1)$ & 64 & .54 & .20 & .18 & 1.0 \\
CPI $(0 \ldots 1)$ & 64 & .50 & .24 & .19 & .97 \\
WBC (0..1) & 64 & .57 & .22 & .28 & .99 \\
POP (Mio.) & 64 & 60.80 & 180.00 & 1.20 & $1,150.00$ \\
GDPPC (\$) & 64 & 7,866 & 8,857 & 95.52 & 31,521 \\
GOVSIZE & 64 & .16 & .05 & .06 & .32 \\
GLOBAL & 64 & .73 & .35 & .19 & 1.57 \\
ETHNO & 64 & .40 & .27 & .02 & .93 \\
PRESS & 64 & 64.9 & 20.7 & 18.1 & 92.7 \\
FEDERAL & 55 & .27 & .45 & 0 & 1 \\
TIERS & 61 & 3.59 & .80 & 2 & 6 \\
EMPLDEC & 51 & .44 & .22 & .08 & .93 \\
EXPDEC & 64 & .22 & .14 & .02 & .57 \\
REVDEC & 64 & .17 & .13 & .01 & .53 \\
\hline
\end{tabular}

\section{Empirical analysis}

\subsection{Benchmark regressions}

As a benchmark case, we first estimate the impact of decentralization on corruption in a cross-country data set without testing for a complementary relationship between decentralization and the effectiveness of monitoring bureaucrat's behaviour. This estimation approach enables us to compare our results with previous research studies on the basis of a broader data set covering up to 64 countries. The basic estimation equation has the form

$$
C O R R U P T_{i}=\alpha+\beta \cdot C O N T R O L_{i}+\gamma \cdot D E C E N T R_{i}+\epsilon_{i}
$$

$\overline{9}$ See Table A2 in the appendix for data sources and definitions. 
where CORRUPT as dependent variable reflects the level of corruption in country $i, C O N T R O L$ is a vector of control variables mentioned above, and DECENTR represents our different decentralization measures. To avoid causality problems, the timing of independent variables is chosen such that they are long averages for the period 1980-1995, prior to the corruption measures for 1996-2000. We are mainly interested in the sign and significance of $\gamma$, which might be positive, supporting the findings of Fisman and Gatti (2002a), Arikan (2004), etc. or negative as in Treisman (2000). Note that the corruption measures reflect the absence of corruption, and thus a positive sign means a high degree of decentralization is associated with low corruption. We present estimation results for three alternative corruption measures as dependent variables and all mentioned decentralization measures, respectively.

Table 4 contains the cross-sectional results. White's test for heteroskedasticity in the residuals rejects the null of no heteroskedasticity; thus, all standard errors of coefficients are calculated using White (1980) correction. The coefficients of our 'de jure' decentralization measures (FEDERAL and TIERS) are insignificant in all specifications. A similar picture occurs for the employment decentralization measure. The 'de facto' decentralization measures (EXPDEC and REVDEC) have no significant impact on corruption with the ICRG index as the corruption measure (specification 4 and 5) as well as with the WBC corruption measure. With the CPI index as the corruption measure, we obtain a positive and weakly significant coefficient for $E X P D E C$ (specification 9). REVDEC barely misses conventional significance levels.

Our control variables show the expected signs and support the findings of earlier studies. The size of a country in terms of population $(P O P)$, the ethnic fractionalization (ETHNO), and the economic openness $(G L O B A L)$ have no significant impact on corruption. Richer countries $(G D P P C)$ show less corruption capturing the effect of better institutions. Moreover, countries with a larger government (GOVSIZE) show less corruption. Last but not least, countries with a high degree of press freedom show less corruption (PRESS). Thus, we conclude from our benchmark analysis that the positive impact of decentralization on the absence of corruption found in almost all earlier studies is very sensitive to the underlying measurement concepts of both decentralization and corruption, as well as to the sample of countries. In the next section, we present evidence that the relationship between corruption and decentralization crucially depends on the effectiveness of monitoring of bureaucrats. 


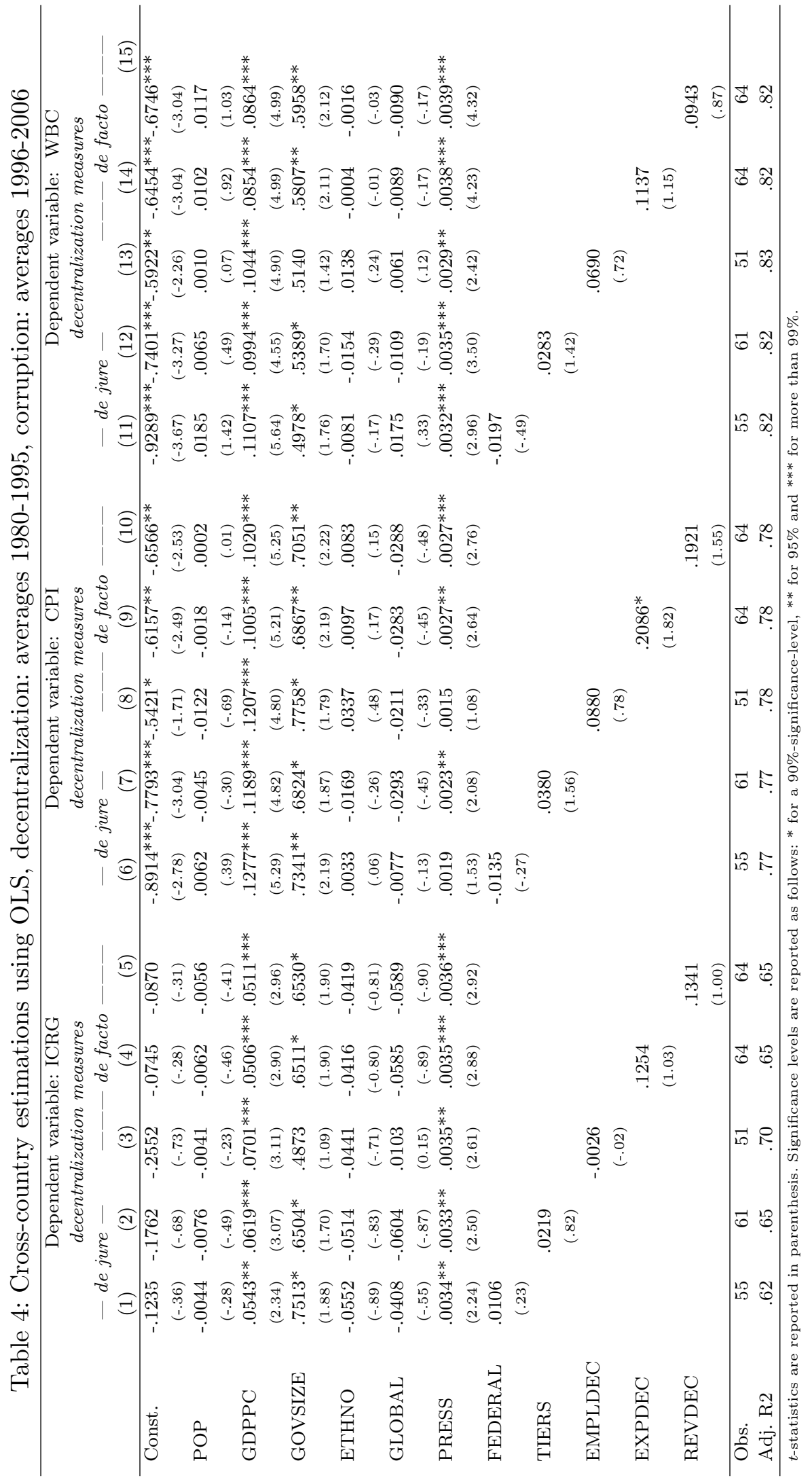




\subsection{Cross-sectional analysis considering monitoring effectiveness}

The hypothesis we test now is that the relationship between decentralization and corruption depends on the effectiveness of monitoring of bureaucrats. As we have discussed in section 2.1, most theoretical studies concerning the relationship between decentralization and corruption assume free information flows between the agents. For this purpose we consider the freedom of the press as an indicator for the monitoring effectiveness and reinvestigate the relationship between decentralization and corruption. As a first step in our analysis we graphically investigate our data, before subsequently specifying an econometric model to test our hypothesis.

Figure 1 shows a scatterplot of our whole data set with our 'de facto' decentralization measure on the abscissa and the ICRG index on the ordinate. The effectiveness of monitoring is considered such that we classified our countries into three groups: the upper third of countries with the highest degree of the freedom of the press measure is marked by quadrangles, countries in the middle third are marked by dots, and those in the lowest third of press freedom are stars. The figure also includes three trendlines, each of which reflects the relationship between decentralization and corruption in the three different groups of countries.

The scatterplot suggests that the relationship between decentralization and corruption indeed depends on the effectiveness of monitoring of bureaucrats reflected by the freedom of the press. Countries with good monitoring show a positive impact of decentralization on the absence of corruption (upper trendline in figure 1), countries with middle monitoring come up with just a weak relationship (continuous line), and in countries with weak monitoring, decentralization is negatively associated with the absence of corruption (dotted line). Inspection of the raw data suggests that there are no important outliers. 


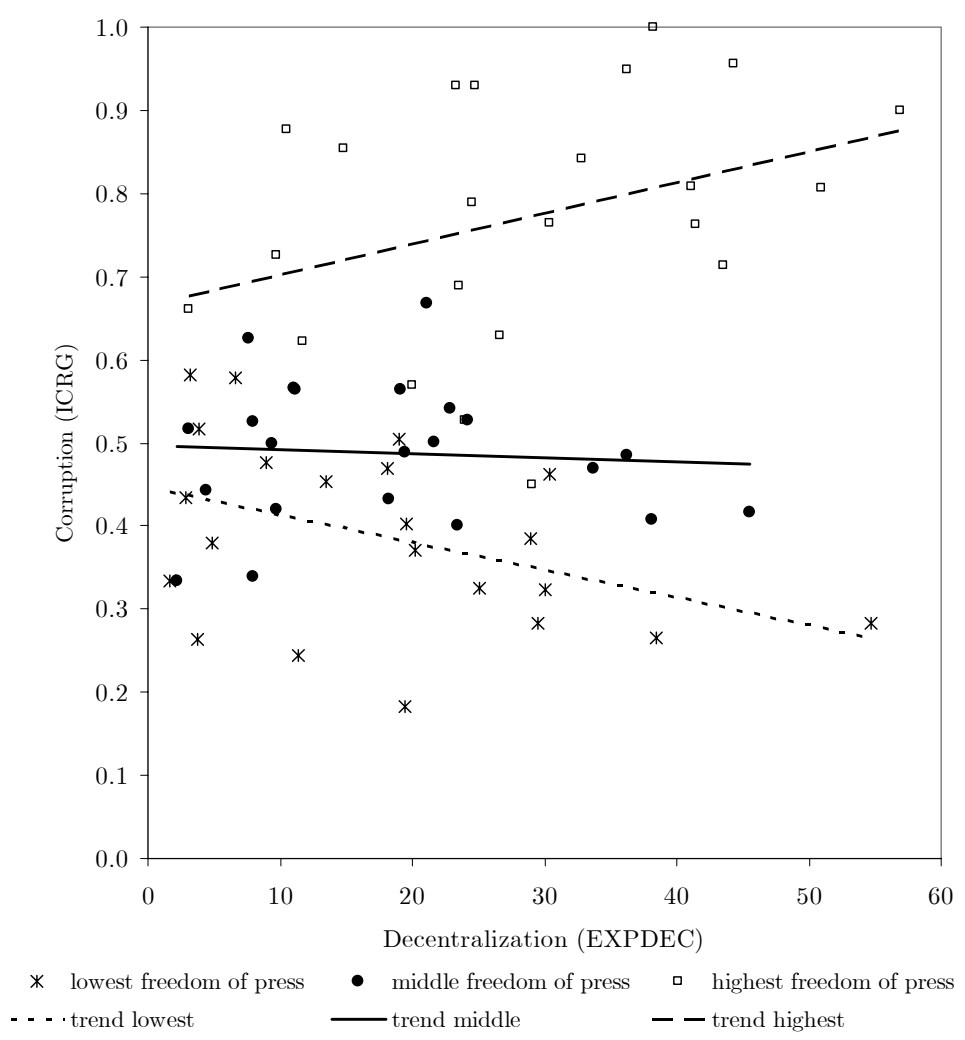

Fig. 1. Decentralization, corruption and freedom of press. Note: decentralization is measured by the degree of expenditure decentralization $(E X P D E C)$, corruption is measured by the ICRG index, and freedom of press are $q$-quantile dummy variables for $q=3$.

Doubtlessly, the inspection of scatterplots is only a first step in answering our research question. Therefore, we set up an econometric model to test our hypothesis empirically. For this purpose, we built dummy variables for $q$-quantiles of the freedom of the press measure $(F P 1 q, \ldots, F P q q)$ and interact them with our decentralization measure in a structural break model. For $q=3$ we exactly estimate the trendlines of figure 1 distinguishing between the upper third, the middle third, and the lower third of countries in respect to the degree of freedom of the press.

The estimation equation now takes the form

$$
\begin{aligned}
\text { CORRUPT }_{i}= & \alpha+\beta \cdot C O N T R O L_{i}+\gamma \cdot D E C E N T R_{i} \\
& +\sum_{k=1}^{q-1} \delta_{k} \cdot\left(D E C E N T R_{i} \cdot F P k q_{i}\right)+\sum_{k=1}^{q-1} \theta_{k} \cdot F P k q_{i}+\epsilon_{i} .
\end{aligned}
$$

The interaction terms of decentralization and the q-quantile dummies show us whether the relationship between decentralization and corruption depends on the monitoring possibilities of bureaucrats. In other words: The interaction terms indicate whether decentralization and effectiveness of monitoring have a complementary effect on cor- 
ruption or not. The FPkq-dummy for the countries with the highest q-quantile of the freedom of the press measure is not considered in the estimations, and, thus, is used as a reference group. $\gamma$ captures the overall impact of decentralization on corruption, while $\delta_{k}$ captures the partial effect of the $k$ interaction terms. We obtain the total effect of decentralization on corruption in the countries by adding the coefficient of an interaction term to the coefficient of the general effect.

Using dummy variables of the freedom of press measure allows us to interpret the results much easier than using interaction terms of two continuous variables. In the latter case the marginal effects have to be calculated from differentiating our estimation equation, while the coefficients of the interaction terms using dummy variables are independent from the other coefficients. Moreover, varying $q$ allows us to test for more than only one structural break in the data as suggested by the graphical inspection of the data (figure 1). Nevertheless, we also report estimation results using a continuous interaction term of decentralization and freedom of the press as a robustness test.

Due to space limitations, we subsequently present estimation results only for the ICRG index as the corruption measure and EXPDEC as the decentralization measure in the body of our paper. ${ }^{10}$ Table 5 presents estimation results for three different models. In specifications (1) and (2), we estimate our model setting $q=2$, which is similar to using just one dummy (FP12) for the $50 \%$ of countries with the lowest degree of freedom of the press. In the next two specifications we set $q=3$, distinguishing between high, middle, and low degrees of freedom of the press, which is a direct test of figure 1. Thus, we have FP13 as a terzile dummy for those countries with the lowest degree of freedom of the press, FP23 as a dummy for those countries with a middle degree of freedom of the press, and FP33 as a dummy for the countries with the highest degree of freedom of the press. Note that FP33 does not enter the regressions, as we use it as a reference group. Furthermore, we drop the PRESS variable in our specifications when considering interaction terms because the impact of the freedom of the press is now covered by our FPkq-dummies. Specifications (5) and (6) present results we obtain using an interaction term of decentralization and the freedom of press measure.

We apply the OLS estimation technique as well as TSLS to handle the problems arising from possible endogeneity bias. In order to control for reverse causation we use the logarithm of each country's area in square kilometers $(A R E A)$ as an instrument for decentralization. An optimal instrument should affect countries' degree of decentralization, but not affect the degree of corruption. The area of a country should not have any direct impact on the level of corruption, but it is often used as an explanatory variable for the degree of fiscal decentralization [see e.g. Wasylenko (1987), Porta et al. (1999), and Arikan (2004)]. We further on use the lag structure as in our benchmark

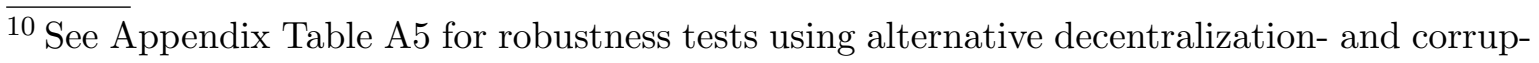
tion measures. 
Table 5

Cross-section estimations considering the effectiveness of public monitoring

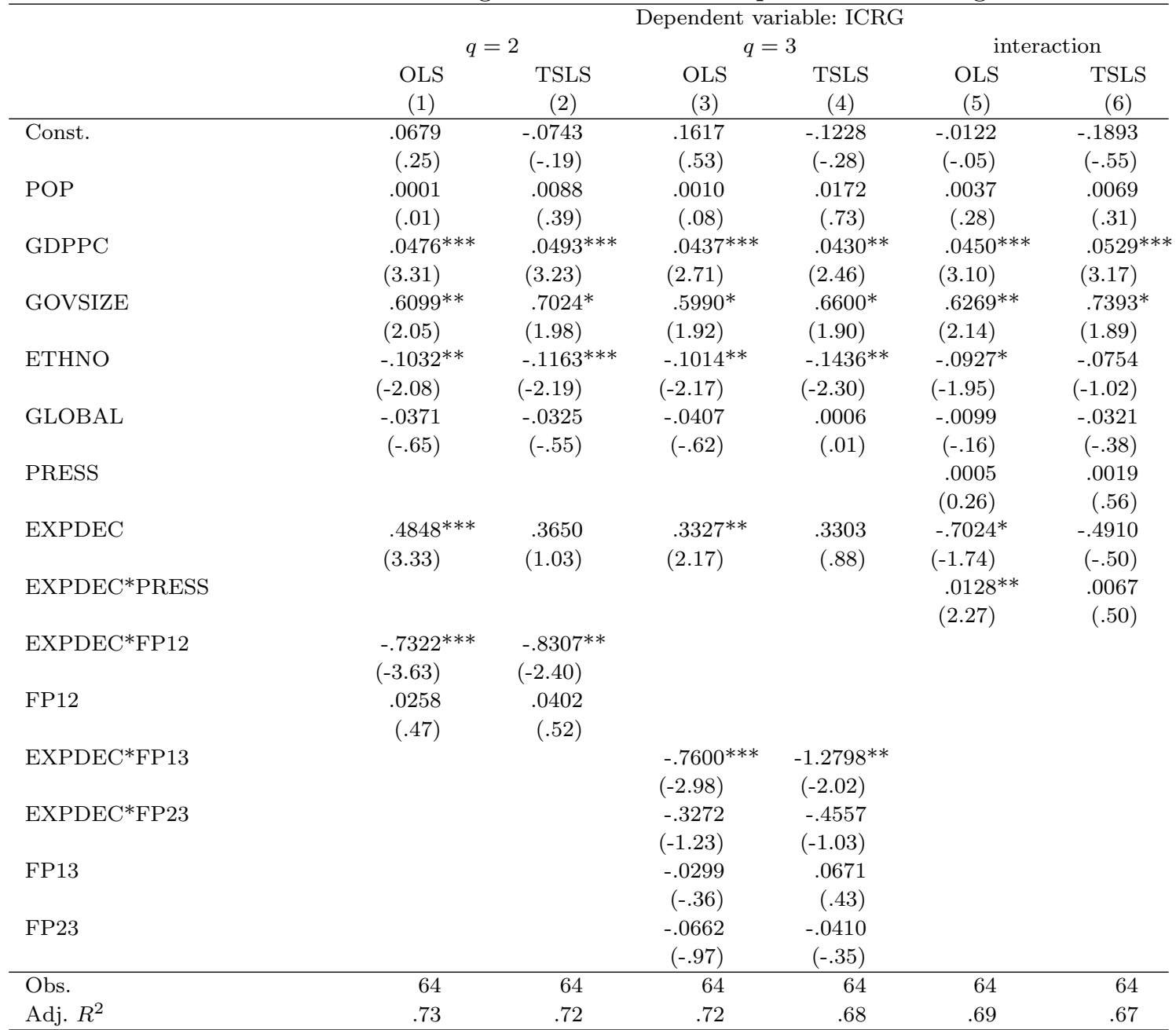

Note: $t$-statistics are reported in parenthesis. Significance levels are reported as follows: ${ }^{*}$ for a $90 \%$-significancelevel, ** for $95 \%$ and ${ }^{* * *}$ for more than $99 \%$.

regressions.

Specifications (1) and (2) show that decentralization has a positive overall impact on corruption, but exerts a negative impact in those countries with a low degree of freedom of the press or in other words: with a less effective monitoring of bureaucrats. On the basis of the coefficient of EXPDEC (0.4848) and the coefficient of the interaction term $E X P D E C^{*} F P 12(-0.7322)$, the aggregate effect of decentralization on corruption in those countries with the $50 \%$ lowest degree of freedom of the press is $0.4848-0.7322=-$ 0.2474 , ergo negative. The strong negative impact also holds for IV-estimations using the logarithm of country's area in square kilometers. Specifications (3) and (4) of Table 5 show estimations similar to the scatterplot of figure 1 . The effect of decentralization on the absence of corruption is in general positive, while it is strongly negative in countries with the lowest degree of freedom of the press $\left(E X P D E C^{*} F P 13\right)$. As the scatterplot 
already indicated we find no effect of decentralization on corruption in countries with a middle degree of freedom of the press. Countries with a high degree of freedom of the press serve as reference group: the coefficient for those countries can be calculated from the other coefficients and remains positive.

The last two specifications in Table 5 present results using interaction terms of decentralization and freedom of the press without building dummy variables. It is important to note that the effect of decentralization on corruption is not only captured by the interaction term. In fact the marginal impact of decentralization on corruption depends both on the interaction term and on decentralization. The cutoff values of freedom of the press, that is, the value of freedom of the press for which $\partial($ corruption $) / \partial($ decentralization $)=0$, is 54.9 , implying that for roughly a third of the countries in the sample, increased decentralization is associated with higher corruption. For countries close to the cutoff value, the effect of decentralization on corruption is small, while the positive impact of decentralization on corruption in countries with a high degree of freedom of press is fairly high. The marginal effect is statistically different from zero, with more than 90 percent confidence with a freedom of press value exceeding roughly 70 . In other words, the impact of decentralization on corruption is significantly positive for nearly 50 percent of countries in our sample. Our results imply that decentralization counteracts corruption in countries with a low degree of freedom of press (see figure 2).

This finding is in line with our results from specifications (3) and (4), which have shown a strong negative impact of decentralization on corruption in one third of countries with the lowest degree of freedom of the press.

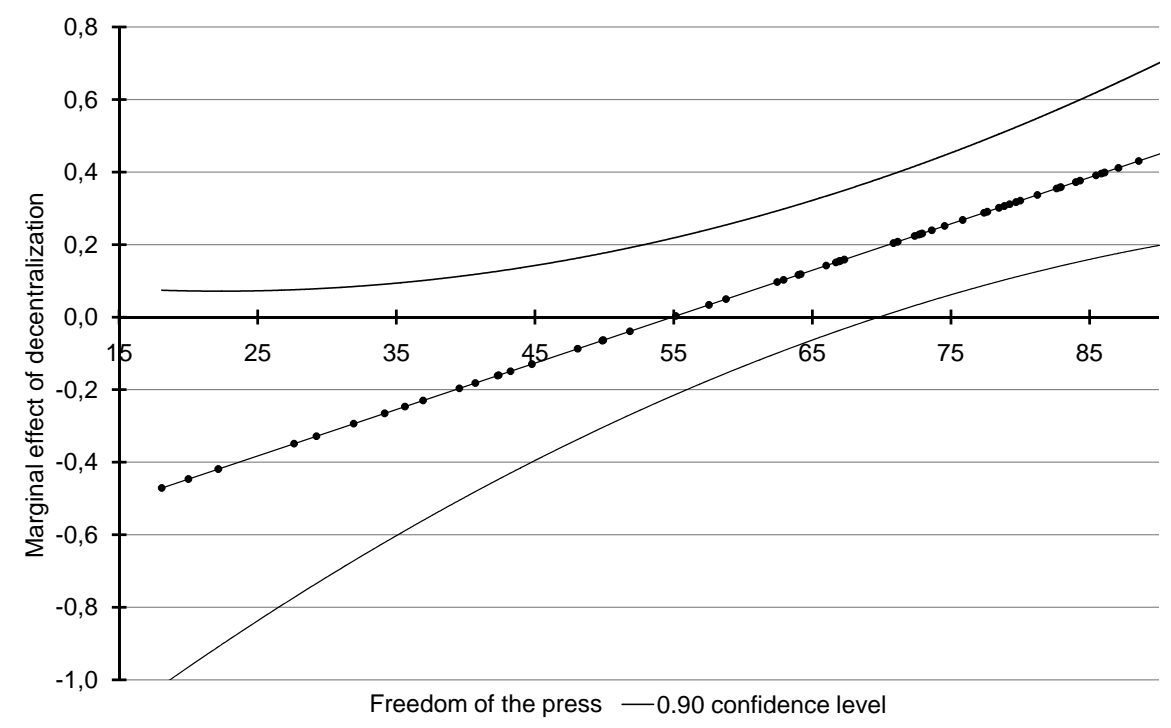

Fig. 2. Marginal effect of decentralization on corruption: Freedom of the press 
Tables A5 and A6 in the appendix shows the major results for robustness tests, using alternative corruption indices $(C P I$ and $W B C)$ as well as a different decentralization measure (REVDEC - specifications (19) to (36) and (EMPLDEC - specification (37) to (54)). The econometric specifications are similar to those of Table 5 , but we do not report coefficients of our control variables due to space limitations. The robustness checks confirm our earlier findings in most specifications.

Hitherto we use averages (1996-2000) of the different corruption indices as dependent variables in our regressions. The dependent variable is therefore a continuous variable and this allows estimates using OLS and TSLS. However, there could be some doubts on the cardinal nature of corruption indices. One could argue that the commonly used corruption perception indices only rank the countries from the most to the least corrupt ones. In this case the indices are ordinal and the relation between the numbers are unknown. A (rescaled) CPI-value of 0.25 does not imply that the country has twice the amount of corruption compared to a country with a value of 0.50 (see Soreide (2005)). This values just means that the former country is more corrupt. Under the interpretation of ordered corruption variable, the OLS and TSLS estimation procedures are not applicable. Instead, with ordinal corruption measures a ordered probit model should be adequate. However, using a ordered probit estimation approach it is difficult to interpret the magnitude and statistical significance of our interaction terms. As it is shown by $\mathrm{Ai}$ and Norton (2003) the marginal effects of the interaction terms in nonlinear models, which are computed by standard statistical software, is incorrect. In addition, the most corruption indices provide explicit numerical ratings with the understanding that they are lineare [see Brunetti and Weder (2003)]. Regarding the severe difficulties in the inference of probit models with interaction terms, we have more confidence to our linear regression results.

Altogether, an examination of the data as well as our regression results show that the impact of decentralization on corruption depends on the effectiveness of monitoring of bureaucrats. As long as monitoring works, decentralization is indeed an effective instrument to keep corruption at bay. Otherwise, if those basic control institutions do not work, decentralization is harmful. This result contrasts the findings of most earlier empirical studies in the field, but is in line with theoretical considerations by, e.g., Tanzi (1995), Prud'homme (1995), andBardhan (2002).

\section{Conclusion}

Fiscal decentralization plays a major role, e.g., in World Bank's anti-corruption and development strategy. Based on earlier studies that found corruption to be lower in decentralized countries, decentralization is assumed to be an appropriate instrument to tackle the corruption disease in developing countries. In line with the majority of the theoretical literature, we argue that the effectiveness of monitoring bureaucrat's 
behavior is an important determinant of the relationship between decentralization and corruption. To test this hypothesis empirically, we have analyzed the impact of decentralization on corruption, taking the degree of freedom of the press into account. For this purpose we applied a broader data set using different decentralization and corruption measures. In contrast to previous studies we are not able to identify a robust impact of decentralization on corruption in general.

In a second step, we have estimated structural break models, considering the effectiveness of monitoring bureaucrat's behavior as measured by freedom of the press. A free and independent press is able to reveal and report misuses of public office for private gain. It complements the competition and accountability effects of decentralization. We find that in countries with an effective monitoring, decentralization has a positive impact on the absence of corruption. Otherwise, if monitoring does not work, decentralization has a negative effect. This association is robust for a wide range of potential sources of omitted variable bias as well as endogeneity bias. We also show that these results are non-sensitive to the underlying measurement concepts of decentralization and corruption.

The policy implications of our study are obvious: decentralization is a feasible instrument to reduce corruption if the monitoring of bureaucrats works. Otherwise, if those institutions do not work sufficiently, decentralization can contribute to high corruption levels. Institutions linking foreign aid to decentralization initiatives should, therefore, carefully consider whether the institutional background of the target countries in terms of an effective public monitoring is adequate. With regard to our research question whether decentralization is in either case the right medicine against the corruption disease, the answer is: No! One size does not fit all. 


\section{References}

Ai, C. and Norton, E. C. (2003), 'Interaction terms in logit and probit models', Economic Letters 80, 123-129.

Arend, R. (2002), Press freedom, human capital and corruption, DELTA Working Papers.

Arikan, G. G. (2004), 'Fiscal decentralization: A remedy for corruption?', International Tax and Public Finance 11, 175-195.

Bardhan, P. (2002), 'Decentralization of governance and development', Journal of Economic Perspectives 16, 185-205.

Bardhan, P. and Mookherjee, D. (2006a), 'Decentralization and accountability in infrastructure delivery in developing countries', Economic Journal 116, 101-127.

Bardhan, P. and Mookherjee, D. (2006b), Decentralization, corruption and government accountability, in S. Rose-Ackerman, ed., 'International handbook on the economics of corruption', Edward Elgar Publishing, Cheltenham, pp. 161-188.

Becker, G. (1968), 'Crime and punishment: an economic approach', Journal of Political Economy 76, 169-217.

Bennett, J. and Estrin, S. (2006), Corruption and bureaucratic structure in a developing economy, IZA Discussion Paper Series 2156.

Besley, T. and Case, A. (1995), 'Incumbent behaviour: vote seeking, tax setting, and yardstick competition', American Economic Review 85, 25-55.

Brunetti, A. and Weder, B. (2003), 'A free press is bad news for corruption', Journal of Public Economics 87, 1801-1824.

Careaga, M. and Weingast, B. R. (2000), The fiscal pact with the devil: A positive approach to fiscal federalism, revenue sharing and good governance, Working Paper, Hoover Institution, Stanford University.

Chowdhury, S. K. (2004), 'The effect of democracy and press freedom on corruption; an empirical test', Economic Letters 85, 93-101.

Development Committee (2006), Strenghtening Bank Group Engagement on Governance and Anticurruption, Joint Ministerial Committee of the Boards of Govenors of the World Bank and the International Monetary Fund on the Transfer of Real Resources to Developing Countries, Washington, D.C.

Dincer, O. D., Ellis, C. J. and Waddell, G. R. (2006), Corruption, decentralization and yardstick competition, Discussion paper University of Oregon.

Fisman, R. and Gatti, R. (2002a), 'Decentralization and corruption: Evidence across 
countries', Journal of Public Economics 83, 325-245.

Fisman, R. and Gatti, R. (2002b), 'Decentralization and corruption: Evidence from u.s. federal transfer programs', Public Choice 113, 25-35.

Freille, S. and Haque, E. and Kneller, R.(2007a), 'Federalsim, decentralization and corruption', Working Paper University of Nottingham.

Freille, S. and Haque, E. and Kneller, R.(2007b), 'A contribution to the empirics of press freedom and corruption', European Journal of Political Economy 23, 838-862.

Huther, J. and Shah, A. (1998), Applying a simple measure of good governance to the debate on fiscal decentralization, World Bank Policy Research Paper 1894.

Kessing, S. G., Konrad, K. A. and Kotsogiannis, C. (2007), 'Foreign direct investment and the dark side of decentralization', Economic Policy 172, 5-70.

Knack, S. and Keefer, P. (1995), 'Institutions and economic performance: cross-country tests using alternative institutional measures', Economics and Politics 3, 207-227.

Lambsdorff, J. G. (2005), Determining trends for perceived levels of corruption, Discussion Paper of the Economics Department, Passau University, V-38-05.

Lederman, D., Loayza, N. V. and Soares, R. R. (2005), 'Accountability and corruption: Political institutions matter', Economics and Politics 17, 1-35.

Litvack, J., Ahmad, J. and Bird, R. M. (1998), Rethinking decentralization in developing countries, World Bank Sector Studies Series.

Oates, W. E. (1972), Fiscal Federalism, McGrwa-Hill, New York.

OECD (1999), Taxing Powers of State and Local Government, OECD Tax Policy Studies No., OECD, Paris.

Persson, T. and Tabellini, G. (2000a), Constitutional determinants of government spending, Working paper series / innocenzo gasparini institute for economic research.

Persson, T. and Tabellini, G. (2000a), Political economics: explaining economic policy, MIT Press, Cambridge MA.

Porta, R. L., de Silanes, F. L., Shleifer, A. and Vishny, R. (1999), 'The quality of government', Journal of Law, Economics and Organization 15(1), 222-279.

Prud'homme, R. (1995), 'The dangers of decentralization', World Bank Research Observer 10, 2, 201-220.

Rodden, J. (2000), The dilemma of fiscal federalism: Hard and soft budget constraints around the world, Mimeo, MIT.

Rodden, J. (2004), 'Comparative federalism and decentralization: on meaning and mea- 
surement', Comparative Politics 36(4), 481-500.

Shleifer, A. and Vishny, R. W. (1993), 'Corruption', Quarterly Journal of Economics 108, 599-611.

Soreide, T. (2005), Is it right to rank?, CMI Working Papers .

Stapenhurst, R. (2000), The media's role in curbing corruption, World Bank Working Papers .

Stegarescu, D. (2005), 'Public sector decentralization: Measurement concepts and recent international trends', Fiscal Studies 26, 3, 301-333.

Tanzi, V. (1995), Fiscal federalism and decentralization: A review of some efficiency and macroeconomic aspects, in 'Proceedings of the Annual World Bank Conference on Development Economics', The World Bank, Washington D.C., pp. 295-316.

Tiebout, C. M. (1956), 'A pure theory of local expenditures', Journal of Political Economy 64, 416-424.

Treisman, D. (2000), 'The causes of corruption: A cross-national study', Journal of Public Economics 76 (3), 399-457.

Treisman, D. (2002), Defining and measuring decentralization: A global persepctive, Mimeo, UCLA.

Wasylenko, M. (1987), 'Fiscal decentralization and economic development', Public Budgeting and Finance 4, 57-71.

White, H. (1980), 'A heteroskedasticity-consistent covariance matrix and a direct test of heteroskedasticity', Econometrica 48, 817-838. 


\section{A Appendix}

Table A1

Pairwise correlation coefficients of different decentralization measures

\begin{tabular}{lccccc}
\hline & \multicolumn{4}{c}{ "de jure" } & "de facto" \\
\cline { 2 - 6 } & FEDERAL & TIERS & EMPLDEC & EXPDEC & REVDEC \\
\hline FEDERAL & 1.0000 & & & & \\
TIERS & .0203 & 1.0000 & & & \\
& & & & & \\
EMPLDEC & $.4115^{* * *}$ & -.0235 & 1.0000 & & \\
EXPDEC & $.5795^{* * *}$ & -.0232 & $.6722^{* * *}$ & 1.0000 & \\
REVDEC & $.5949^{* * *}$ & .0309 & $.6102^{* * *}$ & $.9385^{* * *}$ & 1.0000 \\
\hline Note: ${ }^{* * *},{ }^{* *}$, and & * indicate significance at $1 \%, 5 \%$, and $10 \%$ levels, respectively.
\end{tabular}

Table A2

Data sources and definitions

\begin{tabular}{|c|c|c|}
\hline Variable & Definition & Source \\
\hline POP & Population in Mill. & WDI \\
\hline GDPPC & Gross Domestic Product per capiata in 2000 dollar & WDI \\
\hline GOVSIZE & $\begin{array}{l}\text { Government consumption expenditures as share of } \\
\text { GDP }\end{array}$ & WDI \\
\hline ETHNO & Degree of ethnolinguistic fragtionalization & Ethnologue \\
\hline GLOBAL & Imports plus exports as share of GDP & WDI \\
\hline PRESS & Index of freedom of press (inverted) & Freedom House \\
\hline ICRG & $\begin{array}{l}\text { International Country Risk Guide corruption measure } \\
(0=\text { highest corruption; } 6=\text { absence of corruption })\end{array}$ & PRS Group \\
\hline CPI & $\begin{array}{l}\text { Corruption Perception Index }(0=\text { highest corruption; } \\
10=\text { absence of corruption })\end{array}$ & $\begin{array}{l}\text { Transparency In- } \\
\text { ternational }\end{array}$ \\
\hline WBC & $\begin{array}{l}\text { World Bank corruption measure }(-2.5=\text { highest cor- } \\
\text { ruption; } 2.5=\text { absence of corruption })\end{array}$ & World Bank \\
\hline FEDERAL & $\begin{array}{l}\text { "Dummy variable for federal constitutions: } 0=\text { uni- } \\
\text { tary country; } 1=\text { federal country" }\end{array}$ & Treisman (2002) \\
\hline TIERS & $\begin{array}{l}\text { Index for number and democratization of vertical gov- } \\
\text { ernment tiers }\end{array}$ & Treisman (2002) \\
\hline EMPLDEC & $\begin{array}{l}\text { Share of subnational government employment in total } \\
\text { government employment }\end{array}$ & ILO \\
\hline EXPDEC & $\begin{array}{l}\text { Share of subnational government expentitures in total } \\
\text { government expenditures }\end{array}$ & IMF GFS \\
\hline REVDEC & $\begin{array}{l}\text { Share of subnational government revenues in total gov- } \\
\text { ernment revenues }\end{array}$ & IMF GFS \\
\hline
\end{tabular}


Table A3

Country statistics

\begin{tabular}{|c|c|c|c|c|c|c|}
\hline Country & $\mathrm{POP}$ & GDPPC & GOVSIZE & ETHNO & GLOBAL & PRESS \\
\hline Albania & 3.08 & 1.03 & 11.16 & 0.26 & 0.48 & 43.23 \\
\hline Argentina & 32.70 & 7.04 & 9.73 & 0.21 & 0.19 & 64.00 \\
\hline Australia & 17.30 & 17.05 & 18.71 & 0.13 & 0.37 & 88.54 \\
\hline Austria & 7.79 & 19.82 & 19.48 & 0.54 & 0.81 & 82.85 \\
\hline Azerbaijan & 7.29 & 0.74 & 16.40 & 0.37 & 0.97 & 27.62 \\
\hline Belarus & 10.00 & 1.22 & 20.28 & 0.40 & 1.21 & 20.00 \\
\hline Belgium & 10.00 & 18.67 & 21.98 & 0.73 & 1.41 & 90.77 \\
\hline Bolivia & 6.98 & 0.94 & 12.96 & 0.68 & 0.48 & 75.85 \\
\hline Brazil & 151.00 & 3.26 & 15.35 & 0.03 & 0.19 & 66.69 \\
\hline Bulgaria & 8.55 & 1.57 & 16.45 & 0.22 & 0.91 & 64.15 \\
\hline Canada & 28.20 & 19.59 & 21.47 & 0.55 & 0.63 & 84.31 \\
\hline Chile & 13.40 & 3.60 & 11.50 & 0.03 & 0.57 & 73.62 \\
\hline China & 1150.00 & 0.51 & 12.94 & 0.49 & 0.35 & 18.08 \\
\hline Colombia & 36.20 & 1.85 & 14.00 & 0.03 & 0.34 & 42.31 \\
\hline Costa Rica & 3.15 & 3.46 & 14.64 & 0.05 & 0.79 & 82.92 \\
\hline Croatia & 4.60 & 3.89 & 25.21 & 0.87 & 1.03 & 49.92 \\
\hline Czech Republic & 10.30 & 5.16 & 22.16 & 0.07 & 1.13 & 78.85 \\
\hline Denmark & 5.21 & 25.37 & 26.26 & 0.05 & 0.70 & 90.62 \\
\hline Dominican Republic & 7.25 & 1.81 & 6.42 & 0.31 & 0.71 & 67.00 \\
\hline Estonia & 1.47 & 3.64 & 19.96 & 0.48 & 1.51 & 79.69 \\
\hline Ethiopia & 52.60 & 0.10 & 15.60 & 0.84 & 0.32 & 35.62 \\
\hline Finland & 5.02 & 19.25 & 21.50 & 0.14 & 0.60 & 87.08 \\
\hline France & 56.90 & 19.12 & 23.31 & 0.27 & 0.46 & 77.38 \\
\hline Germany & 80.10 & 19.47 & 20.26 & 0.19 & 0.53 & 85.46 \\
\hline Hungary & 10.40 & 4.09 & 10.64 & 0.16 & 0.90 & 72.69 \\
\hline India & 875.00 & 0.34 & 11.54 & 0.93 & 0.20 & 58.77 \\
\hline Indonesia & 182.00 & 0.59 & 8.86 & 0.85 & 0.55 & 39.54 \\
\hline Iran, Islamic Rep. & 54.50 & 1.36 & 14.24 & 0.80 & 0.33 & 22.15 \\
\hline Ireland & 3.61 & 15.84 & 17.47 & 0.22 & 1.28 & 82.62 \\
\hline Israel & 5.11 & 15.23 & 31.79 & 0.67 & 0.85 & 71.15 \\
\hline Italy & 57.00 & 16.10 & 18.78 & 0.59 & 0.45 & 70.85 \\
\hline Kazakhstan & 15.70 & 1.27 & 12.70 & 0.70 & 0.90 & 31.92 \\
\hline Kenya & 24.30 & 0.36 & 17.53 & 0.90 & 0.59 & 36.92 \\
\hline Latvia & 2.54 & 3.29 & 14.29 & 0.60 & 1.05 & 78.46 \\
\hline Lithuania & 3.57 & 3.26 & 20.46 & 0.34 & 1.04 & 79.23 \\
\hline Malaysia & 19.00 & 2.87 & 13.60 & 0.76 & 1.57 & 34.15 \\
\hline Mexico & 85.40 & 5.23 & 10.09 & 0.14 & 0.42 & 51.85 \\
\hline Moldova & 4.25 & 0.57 & 17.30 & 0.59 & 1.22 & 42.38 \\
\hline Mongolia & 2.13 & 0.48 & 25.55 & 0.33 & 1.20 & 66.00 \\
\hline Netherlands & 15.10 & 19.06 & 24.14 & 0.39 & 1.10 & 86.08 \\
\hline New Zealand & 3.53 & 16.11 & 18.75 & 0.10 & 0.59 & 91.62 \\
\hline Nicaragua & 4.09 & 0.84 & 22.83 & 0.08 & 0.62 & 57.54 \\
\hline Norway & 4.30 & 31.52 & 20.76 & 0.66 & 0.73 & 92.69 \\
\hline Panama & 2.47 & 3.50 & 15.69 & 0.32 & 1.55 & 67.31 \\
\hline Paraguay & 4.33 & 1.50 & 7.26 & 0.35 & 0.62 & 48.08 \\
\hline Peru & 22.30 & 2.01 & 9.83 & 0.38 & 0.33 & 49.85 \\
\hline Philippines & 63.80 & 0.94 & 10.29 & 0.85 & 0.73 & 62.92 \\
\hline Poland & 37.80 & 3.68 & 18.35 & 0.06 & 0.52 & 77.62 \\
\hline Portugal & 10.00 & 8.16 & 16.91 & 0.02 & 0.67 & 84.00 \\
\hline Romania & 22.60 & 1.87 & 10.81 & 0.17 & 0.61 & 55.15 \\
\hline Russian Federation & 145.00 & 1.94 & 17.85 & 0.28 & 0.57 & 40.69 \\
\hline Slovak Republic & 5.28 & 3.53 & 21.62 & 0.31 & 1.15 & 66.92 \\
\hline Slovenia & 1.98 & 8.53 & 20.55 & 0.17 & 1.18 & 74.54 \\
\hline South Africa & 36.60 & 3.06 & 18.46 & 0.87 & 0.50 & 72.77 \\
\hline Spain & 39.10 & 11.22 & 16.76 & 0.44 & 0.44 & 81.23 \\
\hline Sri Lanka & 16.70 & 0.66 & 9.49 & 0.31 & 0.74 & 44.77 \\
\hline Sweden & 8.62 & 22.90 & 27.97 & 0.17 & 0.68 & 90.38 \\
\hline Switzerland & 6.81 & 31.52 & 11.10 & 0.55 & 0.72 & 90.85 \\
\hline Thailand & 55.60 & 1.53 & 11.12 & 0.75 & 0.80 & 62.46 \\
\hline Trinidad and Tobago & 1.22 & 5.77 & 14.55 & 0.70 & 0.84 & 72.92 \\
\hline United Kingdom & 57.70 & 20.10 & 20.22 & 0.14 & 0.53 & 80.00 \\
\hline United States & 257.00 & 28.72 & 16.23 & 0.35 & 0.21 & 85.85 \\
\hline Uruguay & 3.14 & 5.20 & 12.96 & 0.09 & 0.41 & 72.38 \\
\hline Zimbabwe & 10.40 & 0.58 & 18.99 & 0.53 & 0.56 & 29.23 \\
\hline
\end{tabular}


Table A4

Country statistics - continued

\begin{tabular}{|c|c|c|c|c|c|c|c|c|}
\hline Country & ICRG & CPI & WBC & FEDERAL & TIERS & EMPLDEC & EXPDEC & REVDEC \\
\hline Albania & 2.22 & 2.47 & -0.67 & & 3 & 0.12 & 0.20 & 0.02 \\
\hline Argentina & 2.45 & 2.97 & -0.43 & 1 & 3 & 0.76 & 0.38 & 0.32 \\
\hline Australia & 4.85 & 8.67 & 2.00 & 1 & 3 & 0.63 & 0.41 & 0.28 \\
\hline Austria & 4.59 & 7.94 & 1.97 & 1 & 4 & 0.42 & 0.30 & 0.27 \\
\hline Azerbaijan & 1.95 & 1.94 & -1.09 & & 3 & & 0.25 & 0.21 \\
\hline Belarus & 2.77 & 3.55 & -0.75 & 0 & 4 & 0.22 & 0.30 & 0.28 \\
\hline Belgium & 3.73 & 6.58 & 1.41 & 1 & 4 & 0.57 & 0.12 & 0.06 \\
\hline Bolivia & 2.59 & 2.49 & -0.76 & 0 & 4 & 0.11 & 0.18 & 0.18 \\
\hline Brazil & 2.82 & 3.76 & -0.07 & 1 & 4 & 0.86 & 0.34 & 0.25 \\
\hline Bulgaria & 2.93 & 3.73 & -0.26 & 0 & 4 & 0.24 & 0.19 & 0.16 \\
\hline Canada & 5.40 & 8.88 & 2.15 & 1 & 4 & 0.64 & 0.57 & 0.53 \\
\hline Chile & 3.75 & 7.12 & 1.36 & 0 & 4 & 0.34 & 0.08 & 0.06 \\
\hline China & 1.70 & 3.24 & -0.40 & 0 & 5 & 0.93 & 0.55 & 0.51 \\
\hline Colombia & 2.31 & 3.28 & -0.45 & 0 & 3 & 0.82 & 0.29 & 0.19 \\
\hline Costa Rica & 3.96 & 4.91 & 0.73 & 0 & 4 & 0.09 & 0.03 & 0.03 \\
\hline Croatia & 2.86 & 3.51 & -0.08 & & 3 & & 0.09 & 0.09 \\
\hline Czech Republic & 3.42 & 4.46 & 0.40 & 0 & 3 & 0.32 & 0.20 & 0.16 \\
\hline Denmark & 5.74 & 9.64 & 2.36 & 1 & 3 & 0.65 & 0.44 & 0.31 \\
\hline Dominican Republic & 3.10 & 3.10 & -0.48 & 0 & 3 & 0.08 & 0.03 & 0.01 \\
\hline Estonia & 3.77 & 5.88 & 0.63 & 0 & 3 & 0.34 & 0.27 & 0.21 \\
\hline Ethiopia & 2.00 & 2.68 & -0.58 & & 5 & & 0.02 & 0.02 \\
\hline Finland & 6.00 & 9.65 & 2.47 & 0 & 3 & 0.78 & 0.38 & 0.31 \\
\hline France & 3.38 & 6.87 & 1.46 & 0 & 4 & 0.44 & 0.19 & 0.12 \\
\hline Germany & 4.58 & 7.89 & 1.92 & 1 & 4 & 0.87 & 0.41 & 0.35 \\
\hline Hungary & 4.01 & 5.04 & 0.64 & 0 & 3 & 0.48 & 0.21 & 0.12 \\
\hline India & 2.50 & 2.83 & -0.34 & 1 & 5 & 0.49 & 0.46 & 0.33 \\
\hline Indonesia & 1.47 & 2.10 & -0.94 & 0 & 5 & 0.28 & 0.11 & 0.03 \\
\hline Iran, Islamic Rep. & 3.10 & 2.88 & -0.59 & 0 & 4 & & 0.04 & 0.05 \\
\hline Ireland & 3.16 & 7.64 & 1.73 & 0 & 3 & & 0.24 & 0.08 \\
\hline Israel & 3.38 & 6.97 & 1.08 & 0 & 3 & & 0.11 & 0.07 \\
\hline Italy & 3.01 & 4.82 & 0.68 & 0 & 4 & 0.39 & 0.22 & 0.07 \\
\hline Kazakhstan & 1.94 & 2.51 & -1.00 & & 4 & 0.26 & 0.30 & 0.28 \\
\hline Kenya & 2.28 & 2.10 & -1.03 & 0 & 6 & 0.18 & 0.05 & 0.06 \\
\hline Latvia & 2.40 & 3.70 & 0.03 & 0 & 3 & 0.57 & 0.23 & 0.19 \\
\hline Lithuania & 2.70 & 4.55 & 0.19 & & 3 & 0.37 & 0.29 & 0.22 \\
\hline Malaysia & 3.03 & 5.07 & 0.39 & 1 & 3 & 0.32 & 0.19 & 0.16 \\
\hline Mexico & 2.42 & 3.39 & -0.34 & 1 & 3 & 0.29 & 0.20 & 0.20 \\
\hline Moldova & 1.70 & 2.65 & -0.75 & & 3 & 0.53 & 0.29 & 0.27 \\
\hline Mongolia & 2.91 & 3.28 & -0.23 & & & & 0.36 & 0.27 \\
\hline Netherlands & 5.58 & 8.85 & 2.20 & 0 & 3 & 0.25 & 0.25 & 0.08 \\
\hline New Zealand & 5.26 & 9.46 & 2.36 & 0 & 3 & 0.49 & 0.11 & 0.09 \\
\hline Nicaragua & 3.47 & 2.69 & -0.56 & 0 & 4 & & 0.07 & 0.08 \\
\hline Norway & 5.05 & 8.84 & 2.10 & 0 & 3 & 0.38 & 0.33 & 0.22 \\
\hline Panama & 2.00 & 3.40 & -0.31 & 0 & 4 & & 0.02 & 0.02 \\
\hline Paraguay & 1.58 & 1.91 & -1.08 & 0 & 3 & & 0.04 & 0.03 \\
\hline Peru & 2.82 & 3.94 & -0.28 & 0 & 4 & & 0.18 & 0.07 \\
\hline Philippines & 2.52 & 2.82 & -0.49 & 0 & 4 & 0.27 & 0.10 & 0.07 \\
\hline Poland & 3.25 & 4.17 & 0.35 & 0 & 3 & 0.61 & 0.23 & 0.15 \\
\hline Portugal & 4.36 & 6.52 & 1.31 & 0 & & 0.32 & 0.10 & 0.07 \\
\hline Romania & 2.72 & 2.98 & -0.33 & 0 & 3 & & 0.13 & 0.09 \\
\hline Russian Federation & 1.59 & 2.47 & -0.84 & 1 & 4 & 0.34 & 0.38 & 0.40 \\
\hline Slovak Republic & 3.15 & 3.91 & 0.27 & 0 & 4 & 0.40 & 0.08 & 0.08 \\
\hline Slovenia & 3.40 & 5.89 & 0.96 & & 2 & 0.16 & 0.11 & 0.09 \\
\hline South Africa & 3.16 & 4.87 & 0.47 & 0 & & 0.44 & 0.24 & 0.14 \\
\hline Spain & 4.13 & 6.53 & 1.38 & 1 & 4 & 0.60 & 0.24 & 0.15 \\
\hline Sri Lanka & 3.49 & 3.38 & -0.23 & 0 & 4 & 0.18 & 0.03 & 0.04 \\
\hline Sweden & 5.69 & 9.27 & 2.30 & 0 & 3 & 0.56 & 0.36 & 0.33 \\
\hline Switzerland & 4.84 & 8.80 & 2.23 & 1 & 3 & 0.54 & 0.51 & 0.46 \\
\hline Thailand & 2.03 & 3.32 & -0.32 & 0 & 5 & 0.41 & 0.08 & 0.05 \\
\hline Trinidad and Tobago & 2.66 & 4.33 & 0.10 & 0 & 2 & & 0.04 & 0.03 \\
\hline United Kingdom & 4.73 & 8.56 & 2.07 & 0 & 4 & 0.64 & 0.25 & 0.13 \\
\hline United States & 4.28 & 7.57 & 1.76 & 1 & 4 & 0.73 & 0.44 & 0.40 \\
\hline Uruguay & 3.00 & 5.23 & 0.64 & 0 & 2 & 0.34 & 0.09 & 0.10 \\
\hline Zimbabwe & 1.10 & 2.94 & -0.90 & 0 & 5 & 0.28 & 0.19 & 0.17 \\
\hline
\end{tabular}




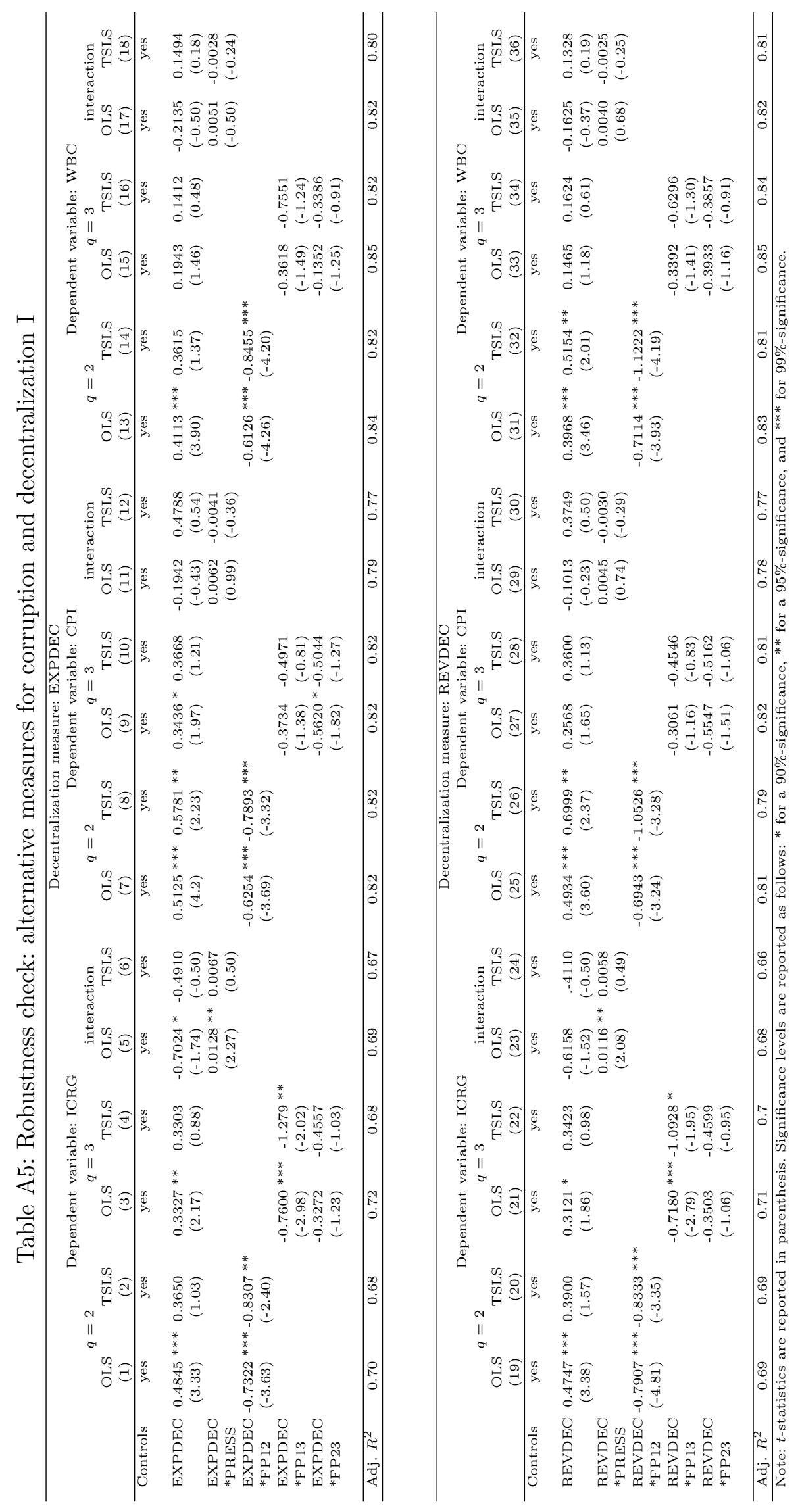




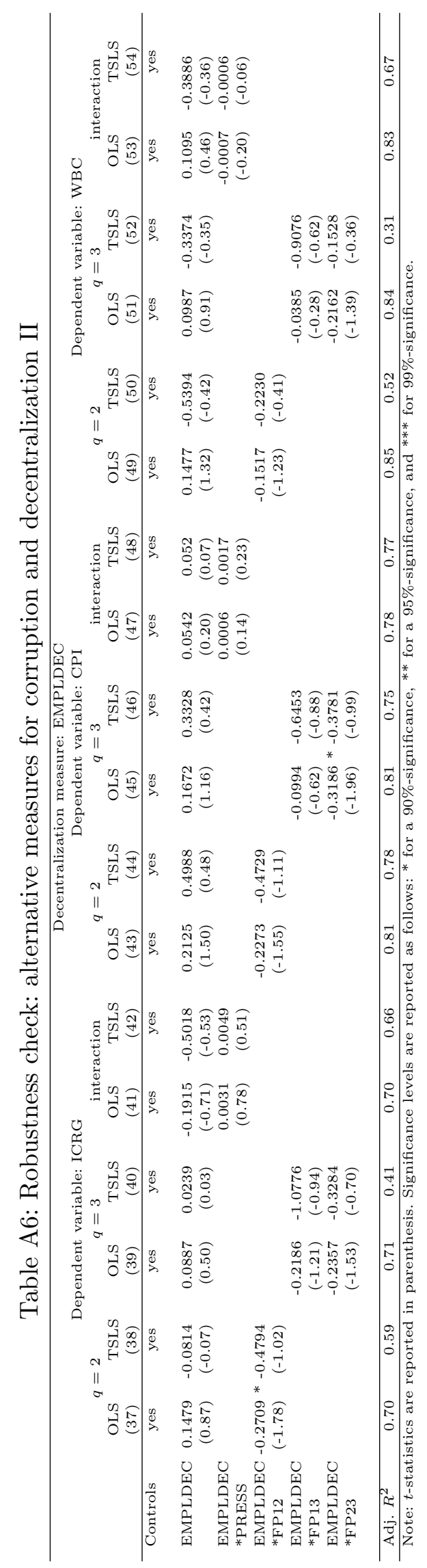




\section{CESifo Working Paper Series}

for full list see www.cesifo-group.org/wp

(address: Poschingerstr. 5, 81679 Munich, Germany, office@cesifo.de)

2601 Ana B. Ania and Andreas Wagener, The Open Method of Coordination (OMC) as an Evolutionary Learning Process, April 2009

2602 Simon Gächter, Daniele Nosenzo, Elke Renner and Martin Sefton, Sequential versus Simultaneous Contributions to Public Goods: Experimental Evidence, April 2009

2603 Philippe Jehiel and Andrew Lilico, Smoking Today and Stopping Tomorrow: A Limited Foresight Perspective, April 2009

2604 Andreas Knabe, Steffen Rätzel, Ronnie Schöb and Joachim Weimann, Dissatisfied with Life, but Having a Good Day: Time-Use and Well-Being of the Unemployed, April 2009

2605 David Bartolini and Raffaella Santolini, Fiscal Rules and the Opportunistic Behaviour of the Incumbent Politician: Evidence from Italian Municipalities, April 2009

2606 Erkki Koskela and Jan König, Can Profit Sharing Lower Flexible Outsourcing? A Note, April 2009

2607 Michel Beine, Frédéric Docquier and Çağlar Özden, Diasporas, April 2009

2608 Gerd Ronning and Hans Schneeweiss, Panel Regression with Random Noise, April 2009

2609 Adam S. Booij, Bernard M.S. van Praag and Gijs van de Kuilen, A Parametric Analysis of Prospect Theory's Functionals for the General Population, April 2009

2610 Jeffrey R. Brown, Julia Lynn Coronado and Don Fullerton, Is Social Security Part of the Social Safety Net?, April 2009

2611 Ali Bayar and Bram Smeets, Economic, Political and Institutional Determinants of Budget Deficits in the European Union, April 2009

2612 Balázs Égert, The Impact of Monetary and Commodity Fundamentals, Macro News and Central Bank Communication on the Exchange Rate: Evidence from South Africa, April 2009

2613 Michael Melvin, Christian Saborowski, Michael Sager and Mark P. Taylor, Bank of England Interest Rate Announcements and the Foreign Exchange Market, April 2009

2614 Marie-Louise Leroux, Pierre Pestieau and Gregory Ponthiere, Should we Subsidize Longevity?, April 2009

2615 Ronald MacDonald, Lukas Menkhoff and Rafael R. Rebitzky, Exchange Rate Forecasters' Performance: Evidence of Skill?, April 2009 
2616 Frederick van der Ploeg and Steven Poelhekke, The Volatility Curse: Revisiting the Paradox of Plenty, April 2009

2617 Axel Dreher, Peter Nunnenkamp, Hannes Öhler and Johannes Weisser, Acting Autonomously or Mimicking the State and Peers? A Panel Tobit Analysis of Financial Dependence and Aid Allocation by Swiss NGOs, April 2009

2618 Guglielmo Maria Caporale, Roman Matousek and Chris Stewart, Rating Assignments: Lessons from International Banks, April 2009

2619 Paul Belleflamme and Martin Peitz, Asymmetric Information and Overinvestment in Quality, April 2009

2620 Thomas Dohmen, Armin Falk, David Huffman and Uwe Sunde, Are Risk Aversion and Impatience Related to Cognitive Ability?, April 2009

2621 Yin-Wong Cheung and Xingwang Qian, The Empirics of China's Outward Direct Investment, April 2009

2622 Frédérique Bec and Christian Gollier, Assets Returns Volatility and Investment Horizon: The French Case, April 2009

2623 Ronnie Schöb and Marcel Thum, Asymmetric Information Renders Minimum Wages Less Harmful, April 2009

2624 Martin Ruf and Alfons J. Weichenrieder, The Taxation of Passive Foreign Investment Lessons from German Experience, April 2009

2625 Yao Li, Borders and Distance in Knowledge Spillovers: Dying over Time or Dying with Age? - Evidence from Patent Citations, April 2009

2626 Jim Malley and Ulrich Woitek, Technology Shocks and Aggregate Fluctuations in an Estimated Hybrid RBC Model, April 2009

2627 Jin Cao and Gerhard Illing, Endogenous Systemic Liquidity Risk, April 2009

2628 Thiess Buettner and Bjoern Kauder, Revenue Forecasting Practices: Differences across Countries and Consequences for Forecasting Performance, April 2009

2629 Håkan Selin, The Rise in Female Employment and the Role of Tax Incentives - An Empirical Analysis of the Swedish Individual Tax Reform of 1971, April 2009

2630 Nick Johnstone and Ivan Hascic, Environmental Policy Design and the Fragmentation of International Markets for Innovation, April 2009

2631 Spiros Bougheas, Richard Kneller and Raymond Riezman, Optimal Education Policies and Comparative Advantage, April 2009

2632 Jay Pil Choi and Heiko Gerlach, Multi-Market Collusion with Demand Linkages and Antitrust Enforcement, April 2009 
2633 Thor O. Thoresen, Income Mobility of Owners of Small Businesses when Boundaries between Occupations are Vague, April 2009

2634 Guido Schwerdt and Amelie C. Wuppermann, Is Traditional Teaching really all that Bad? A Within-Student Between-Subject Approach, April 2009

2635 Kurt R. Brekke, Luigi Siciliani and Odd Rune Straume, Hospital Competition and Quality with Regulated Prices, April 2009

2636 Peter Diamond, Taxes and Pensions, April 2009

2637 Shoshana Grossbard, How "Chicagoan" are Gary Becker's Economic Models of Marriage?, May 2009

2638 Roland Strausz, Regulatory Risk under Optimal Incentive Regulation, May 2009

2639 Holger Zemanek, Ansgar Belke and Gunther Schnabl, Current Account Imbalances and Structural Adjustment in the Euro Area: How to Rebalance Competitiveness, May 2009

2640 Harald Hau and Marcel Thum, Subprime Crisis and Board (In-)Competence: Private vs. Public Banks in Germany, May 2009

2641 Martin Halla, Mario Lackner and Friedrich G. Schneider, An Empirical Analysis of the Dynamics of the Welfare State: The Case of Benefit Morale, May 2009

2642 Balázs Égert, Infrastructure Investment in Network Industries: The Role of Incentive Regulation and Regulatory Independence, May 2009

2643 Christian Gollier, Expected Net Present Value, Expected Net Future Value, and the Ramsey Rule, May 2009

2644 Sören Blomquist and Håkan Selin, Hourly Wage Rate and Taxable Labor Income Responsiveness to Changes in Marginal Tax Rates, May 2009

2645 Dominique Demougin, Oliver Fabel and Christian Thomann, Implicit vs. Explicit Incentives: Theory and a Case Study, May 2009

2646 Francesco C. Billari and Vincenzo Galasso, What Explains Fertility? Evidence from Italian Pension Reforms, May 2009

2647 Kjell Arne Brekke, Karen Evelyn Hauge, Jo Thori Lind and Karine Nyborg, Playing with the Good Guys - A Public Good Game with Endogenous Group Formation, May 2009

2648 Guglielmo Maria Caporale and Luis A. Gil-Alana, Multi-Factor Gegenbauer Processes and European Inflation Rates, May 2009

2649 Henning Bohn, A Static Model for Voting on Social Security, May 2009

2650 Markus Haavio and Kaisa Kotakorpi, The Political Economy of Sin Taxes, May 2009 
2651 Augusto de la Torre, María Soledad Martínez Pería and Sergio L. Schmukler, Drivers and Obstacles to Banking SMEs: The Role of Competition and the Institutional Framework, May 2009

2652 Tobias Lindhe and Jan Södersten, Dividend Taxation, Share Repurchases and the Equity Trap, May 2009

2653 Assaf Razin and Edith Sand, Migration-Regime Liberalization and Social Security: Political-Economy Effect, May 2009

2654 Yin-Wong Cheung and Hiro Ito, A Cross-Country Empirical Analysis of International Reserves, May 2009

2655 Bart Cockx and Bruno Van der Linden, Flexicurity in Belgium. A Proposal Based on Economic Principles, May 2009

2656 Michael Melvin, Lukas Menkhoff and Maik Schmeling, Exchange Rate Management in Emerging Markets: Intervention via an Electronic Limit Order Book, May 2009

2657 Susanne Neckermann, Reto Cueni and Bruno S. Frey, What is an Award Worth? An Econometric Assessment of the Impact of Awards on Employee Performance, May 2009

2658 Steven Brakman, Harry Garretsen and Charles van Marrewijk, Economic Geography within and between European Nations: The Role of Market Potential and Density across Space and Time, May 2009

2659 Giovanni Facchini and Cecilia Testa, Reforming Legislatures: Is one House better than two?, May 2009

2660 Carsten Kowalczyk and Raymond Riezman, Trade Agreements, May 2009

2661 Oliver Falck, Stephan Heblich and Elke Luedemann, Identity and Entrepreneurship, May 2009

2662 Christian Lessmann and Gunther Markwardt, One Size Fits All? Decentralization, Corruption, and the Monitoring of Bureaucrats, May 2009 